\title{
White clover plant morphology in Waikato dairy pastures
}

Dairying Research Corporation, Private Bag 3123, Hamilton

\begin{abstract}
Seasonal changes in white clover plant morphology were investigated in Waikato dairy pasture. Plants were classified according to the degree of branching, 2nd-order plants comprising the bulk of the population (47\%) throughout the year. There was a slightly greater proportion of lst-order plants than found in similar studies on sheep-grazed swards in Manawatu. Plant fragmentation occurred in late spring, increasing the proportion of 1storder plants. A corresponding decrease in plant size was observed, with minimum values measured for most characteristics, i.e., stolon, leaf and root dry weight (DW); stolon length, and number of leaves, roots and growing points. Overall, white clover plants in Waikato dairy pastures are considerably larger than plants in Manawatu sheep pastures. The trial highlighted that because white clover plants in spring are small, they are vulnerable to mismanagement in dairy pastures, just as has been demonstrated in pasture grazed by sheep. There were, however, some significant differences in white clover plant structure in dairy pastures compared with sheep-grazed swards.
\end{abstract}

Keywords: dairy pasture, morphology, plant order, plant size, seasonal variation, Trifolium repens

\section{Introduction}

White clover (Trifolium repens L.) is an essential component of dairy pastures in New Zealand, particularly for its direct influence on milk production through improved forage quality and as a source of nitrogen, Despite its importance, there are no published studies on growth and morphology of individual white clover plants in New Zealand dairy pastures, in contrast with the detailed survey of clover in swards grazed by sheep (Brock et al. 1988; Hay et al. 1988, 1989a).

In pastures grazed by sheep, white clover has a clonal growth form and persists largely through vegetative propagation. Vegetative propagation involves a continuous cycle of growth and branching towards the stolon apices, and death and decay of the older basal portions of stolons. Thus white clover plants vary widely in size and structure throughout the season (Brock et al. 1988). Knowledge of such changes is important, since plant size may influence persistence, productivity and fecundity of individual clover plants within a population (Hay et al. 1988). The aim of this study was to obtain data on seasonal changes in clover plant structure within intensively grazed dairy pastures, providing baseline information for future studies of the effects of various management strategies on white clover morphology and growth.

\section{Materials and methods}

\section{Site}

The trial was located on 6-year-old ryegrasslwhite clover (Grasslands Pitau) pastures at No. 2 Dairy, DRC, Hamilton. Four paddocks, incorporating a combination of 2 soil types (Te Rapa silty peat or Horotiu silt loam/ Hamilton clay loam), grazed at either high (4.53 cows/ ha) or low (3.57 cows/ha) stocking rate by Jersey cows, were selected to give as wide a range of swards as possible. The clover content (\% of DM) of the pastures ranged from 15-26\% over the trial period (May 1992 to May 1993). Regular counts of clover growing points indicated a mean of 610 plants $/ \mathrm{m}^{2}$ (436-777 plants $/ \mathrm{m}^{2}$ ) within the trial site.

\section{Clover plant sampling}

Four turves $(30 \mathrm{~cm} \times 30 \mathrm{~cm}$ to $5 \mathrm{~cm}$ deep) were removed from random locations within each paddock just before each grazing. After removal of soil by washing, all clover plants were separated out and 20 plants selected at random from each turf for further dissection. Plants were assigned an order according to the level of stolon branching, while stolons within plants were classified on the basis of morphological age such that a primary stolon was the oldest or parent stolon. Length, number of leaves, roots, nodes and axillary buds, as well as the presence of a growing point and/or nodal tap-root, were determined for each stolon. Stolons of similar morphological age from each plant were bulked for dry weight while leaf and root dry weights were measured per plant.

\section{Data analysis}

3386 clover plants were dissected. Exclusion of plants cut at the quadrat boundaries tended to be biased against larger plants, as these were more prone to being cut. To counter this effect, all data were weighted before analysis using the model developed by Brock et al. (1988). 


\section{Results}

\section{Meteorological data}

Total rainfall (Ruakura Meteorological station, $1 \mathrm{~km}$ north west of the trial site) for the trial period was 1171 $\mathrm{mm}$, 99\% of the IO-year average, although January, February and April were drier than normal, while July and August were wetter. Grass minimum and soil temperatures were close to or slightly below the 10 year average for each month.

Distribution of plants among orders Individuals within the white clover population ranged from single-stolon, 1storder plants to more complex 6th-order plants. Most plants measured were 2ndorder, averaging $47 \%$ through the trial, while 1st- and 3rd-order plants averaged $25 \%$ and $21 \%$ respectively. Fourth-order plants contributed $6 \%$ while 5th- and 6thorder plants made up only $1 \%$.

Although the proportion of 2 nd-order plants remained relatively constant throughout the season (Figure 1), significant changes were observed in the distribution of plants within other orders. During October to November the proportion of lst-order plants increased from $23 \%$ in September to $44 \%$ in October
Figure 1 Seasonal variation in proportion of plants in each plant order of white clover growing in Waikato dairy pasture.

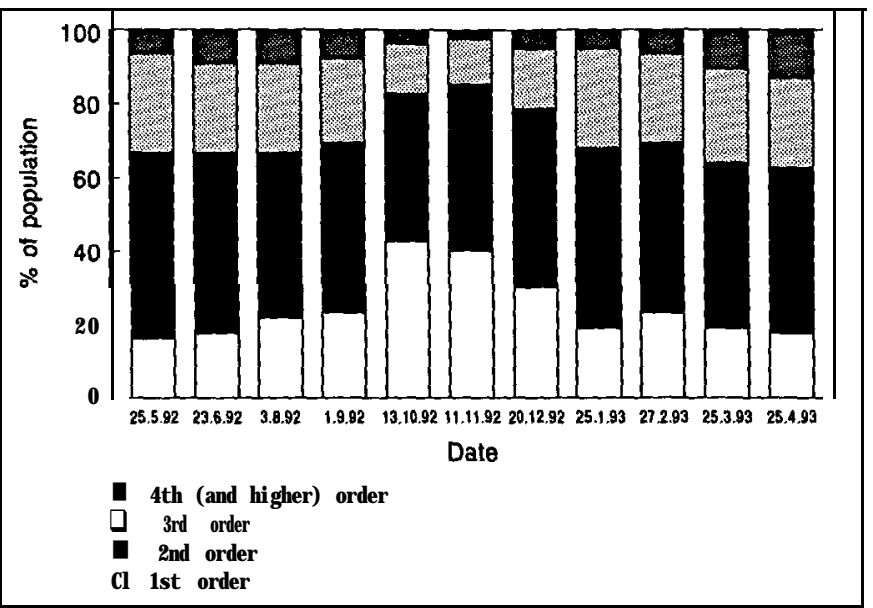

Table 1 Seasonal variation in morphological characteristics of white clover plants in Waikato dairy pasture. Results show mean \pm SE.

\begin{tabular}{|c|c|c|c|c|c|c|c|c|c|c|c|}
\hline Sanple date & $25 / 05 / 92$ & $23 / 06 / 92$ & $3 / 08 / 92$ & $1 / 09 / 921$ & $13 / 10 / 92$ & $11 / 11 / 92$ & $20 / 12 / 92$ & $25 / 01 / 93$ & $27 / 02 / 93$ & $25 / 03 / 93$ & $25 / 04 / 93$ \\
\hline $\begin{array}{l}\text { Nb. stolons } \\
/ \text { plant }\end{array}$ & $\begin{array}{r}5.90 \\
\text { to. } 40\end{array}$ & $\begin{array}{r}6.12 \\
\text { to. } 37\end{array}$ & $\begin{array}{r}6.36 \\
\pm 0.48\end{array}$ & $\begin{array}{r}6.10 \\
\pm 0.41\end{array}$ & $\begin{array}{r}3.12 \\
\text { to. } 17\end{array}$ & $\begin{array}{r}3.35 \\
\pm 0.22\end{array}$ & $\begin{array}{r}5.66 \\
\pm 0.30\end{array}$ & $\begin{array}{r}5.56 \\
\pm 0.40\end{array}$ & $\begin{array}{r}6.09 \\
\pm 0.35\end{array}$ & $\begin{array}{r}7.44 \\
\pm 0.60\end{array}$ & $\begin{array}{r}9.19 \\
\pm 0.65\end{array}$ \\
\hline $\begin{array}{l}\text { Stol on l ength } \\
\qquad / \mathrm{pl} \text { ant }(\mathrm{nm})\end{array}$ & $\begin{array}{r}169.12 \\
16.04\end{array}$ & $\begin{array}{r}154.07 \\
\pm 9.27\end{array}$ & $\begin{array}{r}207.50 \\
t 13.66\end{array}$ & $\begin{array}{r}191.61 \\
\pm 13.02\end{array}$ & $\begin{array}{r}146.05 \\
\pm 7.13\end{array}$ & $\begin{array}{r}132.69 \\
\text { a6. } 26\end{array}$ & $\begin{array}{r}156.19 \\
\text { t6. } 90\end{array}$ & $\begin{array}{r}156.66 \\
t 6.46\end{array}$ & $\begin{array}{r}152.96 \\
\pm 9.58\end{array}$ & $\begin{array}{r}199.49 \\
\text { t13. } 22\end{array}$ & $\begin{array}{r}174.73 \\
\pm 10.64\end{array}$ \\
\hline $\begin{array}{l}\text { Stol on DW } \\
\quad / p l \text { ant }(\mathrm{mg})\end{array}$ & $\begin{array}{l}102.76 \\
\pm 5.28\end{array}$ & $\begin{array}{r}112.07 \\
\pm 7.25\end{array}$ & $\begin{array}{r}116.21 \\
\text { i } 6.36\end{array}$ & $\begin{array}{r}103.43 \\
\pm 7.72\end{array}$ & $\begin{array}{r}74.35 \\
\pm 4.60\end{array}$ & $\begin{array}{l}71.09 \\
\pm 4.98\end{array}$ & $\begin{array}{l}77.35 \\
\text { t4. } 61\end{array}$ & $\begin{array}{r}100.77 \\
\text { A } 66\end{array}$ & $\begin{array}{l}94.93 \\
\pm 6.32\end{array}$ & $\begin{array}{r}121.43 \\
\text { i } 6.47\end{array}$ & $\begin{array}{r}101.35 \\
\text { i } 6.69\end{array}$ \\
\hline $\begin{array}{l}\text { Ratio stol on } \\
\text { length:DW }\end{array}$ & $\begin{array}{r}1.72 \\
\pm 0.03\end{array}$ & $\begin{array}{r}1.52 \\
\pm 0.03\end{array}$ & $\begin{array}{r}1.94 \\
\pm 0.03\end{array}$ & $\begin{array}{r}2.15 \\
\pm 0.05\end{array}$ & $\begin{array}{r}2.23 \\
\pm 0.04\end{array}$ & $\begin{array}{r}2.08 \\
\pm 0.03\end{array}$ & $\begin{array}{r}2.29 \\
\text { to. } 05\end{array}$ & $\begin{array}{r}1.71 \\
\pm 0.03\end{array}$ & $\begin{array}{r}1.61 \\
\text { to. } 04\end{array}$ & $\begin{array}{r}1.61 \\
\pm 0,04\end{array}$ & $\begin{array}{r}1.93 \\
\pm 0.04\end{array}$ \\
\hline $\begin{array}{l}\text { No. nodes } \\
\text { /plant }\end{array}$ & $\begin{array}{l}44.03 \\
\text { i } 2.27\end{array}$ & $\begin{array}{l}47.73 \\
\text { t2. } 47\end{array}$ & $\begin{array}{l}57.46 \\
\mathrm{t} 3.53\end{array}$ & $\begin{array}{l}57.70 \\
\pm 3.55\end{array}$ & $\begin{array}{l}41.47 \\
\pm 2.00\end{array}$ & $\begin{array}{l}41.26 \\
\pm 2.66\end{array}$ & $\begin{array}{l}45.73 \\
\pm 2.21\end{array}$ & $\begin{array}{l}47.46 \\
\pm 2.51\end{array}$ & $\begin{array}{l}47.66 \\
\pm 2.43\end{array}$ & $\begin{array}{l}55.25 \\
\text { t4. } 10\end{array}$ & $\begin{array}{l}69.35 \\
\pm 4.14\end{array}$ \\
\hline $\begin{array}{l}\text { Nb. growing } \\
\text { points/pl ant }\end{array}$ & $\begin{array}{r}5.21 \\
\text { to. } 31\end{array}$ & $\begin{array}{r}5.06 \\
\pm 0.29\end{array}$ & $\begin{array}{r}4.70 \\
\text { to. } 37\end{array}$ & $\begin{array}{r}4.45 \\
\pm 0.28\end{array}$ & $\begin{array}{r}2.46 \\
10.13\end{array}$ & $\begin{array}{r}3.09 \\
\pm 0.21\end{array}$ & $\begin{array}{r}4.63 \\
t 0.26\end{array}$ & $\begin{array}{r}3.66 \\
\pm 0.22\end{array}$ & $\begin{array}{r}5.06 \\
\text { i } 0.29\end{array}$ & $\begin{array}{r}6.32 \\
\text { to. } 54\end{array}$ & $\begin{array}{r}7.29 \\
\pm 0.54\end{array}$ \\
\hline $\begin{array}{l}\text { Nb. axillary } \\
\text { buds/pl ant }\end{array}$ & $\begin{array}{r}1.19 \\
\pm 0.11\end{array}$ & $\begin{array}{r}1.19 \\
\pm 0.11\end{array}$ & $\begin{array}{r}1.13 \\
\pm 0.11\end{array}$ & $\begin{array}{r}1.33 \\
\text { to. } 14\end{array}$ & $\begin{array}{r}0.71 \\
\text { t0. } 06\end{array}$ & $\begin{array}{r}1.04 \\
\mathrm{a} 0.09\end{array}$ & $\begin{array}{r}0.64 \\
\text { to. } 07\end{array}$ & $\begin{array}{r}0.91 \\
\pm 0.09\end{array}$ & $\begin{array}{r}1.69 \\
\text { to. } 15\end{array}$ & $\begin{array}{r}1.45 \\
\text { to. } 22\end{array}$ & $\begin{array}{r}1.30 \\
\text { to. } 11\end{array}$ \\
\hline $\begin{array}{l}\text { Nb. I eaves } \\
/ \text { plant }\end{array}$ & $\begin{array}{r}14.73 \\
\pm 0.82\end{array}$ & $\begin{array}{l}12.62 \\
\text { i } 0.74\end{array}$ & $\begin{array}{l}11.91 \\
\text { il. } 03\end{array}$ & $\begin{array}{r}11.74 \\
\pm 0.74\end{array}$ & $\begin{array}{r}7.36 \\
t 0.36\end{array}$ & $\begin{array}{l}10.44 \\
\pm 0.75\end{array}$ & $\begin{array}{l}14.64 \\
\text { t0. } 63\end{array}$ & $\begin{array}{r}13.25 \\
t 0.66\end{array}$ & $\begin{array}{l}16.14 \\
\text { il. } 11\end{array}$ & $\begin{array}{l}22.46 \\
k 1.66\end{array}$ & $\begin{array}{r}16.75 \\
\pm 1.11\end{array}$ \\
\hline $\begin{array}{l}\text { Leaf } \\
\quad \text { DW Sa } 74 \\
/ \text { pl ant } \\
(\mathrm{ny})\end{array}$ & $\begin{array}{l}55.65 \\
\pm 3.72\end{array}$ & $\begin{array}{l}55.39 \\
\pm 3.74\end{array}$ & $\begin{array}{l}66.96 \\
\pm 4.69\end{array}$ & $\begin{array}{l}61.73 \\
\pm 4.68\end{array}$ & $\begin{array}{l}61.74 \\
\text { t3. } 37\end{array}$ & $\begin{array}{l}77.45 \\
\text { i } 4.65\end{array}$ & $\begin{array}{l}71.94 \\
\pm 4.60\end{array}$ & $\begin{array}{l}54.56 \\
\pm 4.12\end{array}$ & $\begin{array}{l}61.40 \\
\text { t3. } 69\end{array}$ & $\begin{array}{l}65.32 \\
\text { t5. } 57\end{array}$ & \pm 4.10 \\
\hline Nb, $\begin{array}{c}\text { rool s14. } 65 \\
/ \text { pl ant }\end{array}$ & $\begin{array}{l}16.04 \\
\pm 0.72\end{array}$ & $\begin{array}{l}22.63 \\
\mathrm{i} 0.93\end{array}$ & $\begin{array}{l}26.50 \\
\text { il } .44\end{array}$ & $\begin{array}{r}15.59 \\
\pm 1.83\end{array}$ & $\begin{array}{r}9.95 \\
\text { t } 0.60\end{array}$ & $\begin{array}{r}11.66 \\
i 0.65\end{array}$ & $\begin{array}{r}7.94 \\
\pm 0.57\end{array}$ & $\begin{array}{r}7.56 \\
\pm 0.38\end{array}$ & $\begin{array}{l}10.20 \\
\text { to. } 43\end{array}$ & $\begin{array}{l}16.54 \\
10.70\end{array}$ & $\pm 1,06$ \\
\hline $\begin{array}{l}\text { Root DM6. } 52 \\
\text { Iplant (ny) }\end{array}$ & $\begin{array}{l}45.59 \\
\pm 2.97\end{array}$ & $\begin{array}{l}46.07 \\
\text { i } 2.66\end{array}$ & $\begin{array}{l}51.55 \\
\text { i } 3.62\end{array}$ & $\begin{array}{l}41.01 \\
\text { t3. } 36\end{array}$ & $\begin{array}{l}33.34 \\
\pm 2.20\end{array}$ & $\begin{array}{l}31.75 \\
\text { i } 2.43\end{array}$ & $\begin{array}{l}36.21 \\
\pm 1.77\end{array}$ & $\begin{array}{l}40.45 \\
\pm 2.34\end{array}$ & $\begin{array}{l}56.92 \\
\pm 2.72\end{array}$ & $\begin{array}{l}49.05 \\
\text { i } 3.61\end{array}$ & \pm 2.90 \\
\hline
\end{tabular}


with the increase in proportion of Ist-order plants. This trend is most obviously expressed in the number of stolons per plant, which was halved between the start of September and mid October. Mean stolon length and stolon DW per plant were both at a minimum during late spring, although the stolon length:DW ratio was higher over this period, indicating stolons were generally thinner per unit length than during the rest of the year. The number of growing points per plant was also lowest during October to November. This is obviously related to the decrease in stolon number, since number of growing points per stolon was actually greatest over this period. As would be expected, owing to the greater proportion of smaller lst-order plants, axillary bud number per plant was also at a minimum in late spring. Maximum bud number at the February sampling preceded an increase in stolon number per plant over March, indicating a period of branch development. Leaf number and leaf DW per plant also decreased over late spring, although climate probably also influenced leaf DW, with low values recorded over winter when temperatures were cooler. A large increase occurred in leaf DW in March when rainfall was considerably higher than normal. Most root development occurred over August-September, as indicated by the increase in root number per plant (Table 1).

\section{Discussion}

White clover plant morphology and growth is influenced by a number of factors, including cultivar, climate, soil type, companion species, farm management (i.e., rotational grazing or set-stocking), and grazing effects (i.e., cattle or sheep) (Brock et al. 1988; Hay et al. 1989a; Pinxterhuis et al. 1993). Interactions between these factors could affect white clover morphology. This study, for example, indicates there are morphological differences between white clover (Pitau) plants at DRC's No. 2 Dairy in Hamilton and plants (Grasslands Huia) in sheep-grazed pastures in Palmerston North (Brock et al. 1988). Whether it is possible to extend these findings and say the "type" of white clover in Waikato dairy pastures is different from that in Manawatu sheep pastures is more uncertain, although it is probably safe to generalise to a certain extent.

Second-order plants comprise the bulk of the white clover population in both sheep and beef cattle grazed pastures in the Manawatu (Brock et al. 1988; Hay et al. 1989a; Pinxterhuis et al. 1993) and in Waikato dairy pastures. However, there was a slightly larger proportion of lst-order plants, and correspondingly smaller proportion of 3rd-order plants, in Waikato dairy pastures than in Manawatu sheep pastures. Pinxterhuis et al. (1993) also reported a higher proportion of 1storder plants and lower percentage of 3rd- and 4th-order plants in set-stocked and rotationally grazed beef cattle pastures. The factors that lead to the increased proportion of 1st order plants on cattle grazed pastures remain unclear, although it is more likely to be related to a grazing effect, i.e., cattle versus sheep, than to a farm management effect, since there is no difference in the distribution among plant orders between rotationally grazed or set-stocked sheep (Brock et al. 1988; Hay et al. 1988) or between rotationally grazed or set-stocked beef cattle (Pinxterhuis et al. 1993) pastures.

Despite the greater proportion of lst-order plants, white clover plants in Waikato dairy pastures were generally larger, with larger plant organs, than those in Manawatu sheep pastures (Brock et al. 1988). Stolon DW per plant, for example, was on average $70 \%$ greater in dairy pastures, while leaf DW, leaf number and stolon length per plant were all approximately $40 \%$ higher. However, number of stolons and growing points per plant were fewer than in sheep pastures, but these characteristics are more directly linked to plant order, since 1st-order plants can only have one stolon with a maximum of one growing point, and therefore mean values are affected by the larger proportion of 1st-order plants in dairy pastures. If mean values for various plant characteristics are compared on a plant order basis (data not shown), the number of stolons and growing points per plant within each order was similar to those on sheep-grazed pastures, while the differences in characteristics such as stolon length and DW per plant were greater.

A number of factors may contribute to the larger size (DW) of plants in dairy pastures. Firstly, Pitau white clover is recognised as being larger leaved and having thicker stolons than Huia (Caradus 1986). Several studies have reported larger size (DW) of white clover plants under rotational grazing by sheep compared with set-stocked systems (Hay et al. 1989a; Brock et al. 1988). Rotational grazing may favour larger size of plants by allowing time for recovery of leaf area and therefore greater growth between grazings (Brock et al. 1988), although the different patterns of defoliation do not affect leaf number or branching complexity (Chapman 1983; Brock et al. 1988). Pinxterhuis et al. (1993), however, report no significant management effects on plant size under cattle grazing. Increased plant size in dairy pastures may also be due to lower grazing stress levels on white clover plants compared with sheep pastures which are generally grazed more severely. Briseno de la $\mathrm{Hoz}$ \& Wilman (1981) found larger plant organs under cattle grazing compared with sheep grazing, even when swards in each system were maintained at similar heights. Rotationally grazed cattle 
pastures also tend to have lower ryegrass tiller densities than set-stocked sheep pastures, which could reduce competition and therefore promote growth of larger white clover plants. Mean ryegrass tiller density at No. 2 Dairy was measured at $5090 / \mathrm{m}^{2}$, considerably less than reported for set-stocked sheep pastures (Hay et al. 1988).

The dramatic increase in the proportion of 1storder plants and decrease in mean plant size in spring appears common to white clover in Waikato dairy pastures as well as Manawatu sheep and beef pastures. These changes are due to fragmentation of larger plants after decay of older stolon material with increased soil temperatures and microbial activity. It is recognised that small size and simple structure of plants in spring makes the white clover population particularly vulnerable to stress (Brock et al. 1988; Hay et al. 1988). Thus small clover plants in spring are vulnerable to stock treading damage which often occurs on dairy farms under conditions of decreased rotation length combined with high rainfall. Since clover stolons in spring have a low starch content, which means their energy reserves are only $10-15 \%$ of those in autumn (Hay et al. 1989b), plants may also be slow to recover from such damage. In addition, ryegrass growth is maximum during spring which will place further stress on small, newly established clover plants. Furthermore, soil nematodes that affect clover, particularly root knot nematode, cause most damage to newly formed roots over spring, which may result in death of small, 1storder plants.

White clover populations in dairy pastures could be severely damaged in spring if managed incorrectly. Although 1st-order plants contribute only a small proportion to the total amount of leaf, stolon and growing points in the white clover population, even during spring, they are important for vegetative reproduction and damage of these plants will obviously reduce the productivity and persistence of white clover throughout the remainder of the year. Greater understanding of seasonal changes in white clover plant morphology in dairy pastures should lead to management systems more conducive to clover growth.

\section{ACKNOWLEDGEMENTS}

The author wishes to thank Dave Clark, Fiona Clarkson and Deanne Waugh for assistance with plant sampling and data entry.

\section{REFERENCES}

Briseno de la Hoz, V.M.; Wilman, D. 1981. Effects of cattle grazing, sheep grazing, cutting and sward height on a grass-white clover sward. Journal of agricultural research, Cambridge 97: 699-706.

Brock, J.L.; Hay, M.J.M.; Thomas, V.J.; Sedcole, J.R. 1988. Morphology of white clover (Trifolium repens L.) plants in pastures under intensive sheep grazing. Journal of agricultural science, Cambridge 111: 273-283.

Caradus, J.R. 1986. World checklist of white clover varieties. New Zealand journal of experimental agriculture 14: 119-164.

Chapman, D.F. 1983. Growth and demography of Trifolium repens stolons in grazed hill pastures. Journal of-applied ecology 20: 597-606.

Hay, M.J.M.; Brock, J.L.; Thomas, V.J.; Knighton, M.V. 1988. Seasonal and sheep grazing management effects on branching structure and dry weight of white clover plants in mixed swards. Proceedings of the New Zealand Grassland Association 49: 197 201.

Hay, M.J.M.; Brock, J.L.; Thomas, V.J. 1989a. Characteristics of individual white clover plants in grazed swards. Proceedings of the XVI International Grassland Congress: 1051-1052.

Hay, M.J.M.; Chu, A.C.P.; Knighton, M.V.; Wewala, S. 1989b. Variation with season and node position in carbohydrate content of white clover stolons. Proceedings of the $\mathrm{XVI}$ International Grassland Congress: $1059-1060$.

Pinxterhuis, I.; Chapman, D.F.; Hay, M.J.M. 1993. Structure of white clover populations and plants in pastures grazed by beef cattle. Proceedings of the XVII International Grassland Congress: 138- 140. 